\title{
ETHNIC IDENTITY (GEO)POLITICS AS A ZERO-SUM GAME. TOWARDS AN ASSESMENT OF THE LONG-TERM EFFECTS OF THE OHRID FRAMEWORK AGREEMENT
}

\author{
Adela M. GJORGJIOSKA, \\ Independent Researcher
}

\begin{abstract}
Since 2001 the inter-ethnic relations between the two largest ethno-national communities in the Republic of Macedonia have been regulated by the Ohrid Framework Agreement (OFA). ${ }^{2}$ Describing it as an attempt at Complex Power Sharing, the article explores the synthesis (in theory and in practice) between the Agreement's consociational and integrationist tenets. Situating the genesis and implementation of the OFA at the intersection of internal and international relations and processes, it considers the influence of two strongly interrelated processes: the country's neoliberal transformation and its accession path to the EU and NATO. Specific internal and international developments in the post-2001 period is analysed in order to illustrate the entrenchment of consociationalism at the expense of integrationism. As a result of these mutually reinforcing structures and processes, it is argued, inter-ethnic relations in the country have become a zero-sum game, which has eroded the scope for sustainable conflict resolution and inter-ethnic stability.
\end{abstract}

Keywords: power sharing, conflict resolution, identity politics, Macedonia, Ohrid Framework Agreement, Prespa Agreement.

\section{Introduction}

Following the collapse of Yugoslavia, the newly independent Republic of Macedonia embarked upon a sweeping socio-economic transformation shaped by the ideological precepts of neoliberalism (Harvey, 2005). As elsewhere, its far-reaching consequences have included the mass privatization of public assets and services, vastly diminished state responsibility over areas of social welfare, increase in all-round inequality and poverty and the rapid depletion of resources (Brown, 2003). On a (social) psychological level the internalization of neoliberal norms has reconstituted social actors into "atoms" of self-interest who navigate the social realm using rational choice and costbenefit calculations grounded on market-based principles. These have become the main social organising principles to the exclusion of all other ethical values and interests (Augoustinos \&

\footnotetext{
1 Contact address: ma_gorgioska@yahoo.com

2 The OFA regulates the inter-ethnic relations between Macedonians and ethnic Albanians. Among other things, it addresses the issue of ethnic-Albanian representation and the use of Albanian language in the public sector.
} 
Walker, 1995, p. 293). What is more, under the ideological influence of neoliberalism, the politics of redistribution has come to be completely sidelined by the politics of recognition. The demands for the "recognition of difference" in particular fueled the struggles of groups mobilized under the banner of ethnicity. This became particularly palpable in 2001, when a violent inter-ethnic conflict was waged for almost 8 months and ended with the signing of the OFA.

These turbulent processes unraveled in the context of Macedonia's membership bid to join the EU and NATO. As the ideological backdrop to the country's geo-political integration to the Euro-Atlantic structures, the adoption of neoliberalism thus became a pervasive influence, which did not bypass its inter-ethnic relations. The phrase "ethnic identity (geo)politics" is used here as an umbrella term to describe the complex interaction between inter-ethnic relations at the intersection of the ideological and geo-political influences of neoliberalism and Euro-Atlanticism. Its long-term repercussions in the Macedonian context are analysed in relation to the implementation of the OFA, as well as its broader impact on inter-ethnic relations and conflict resolution in the country.

\section{The internal and international pressures of ethnic identity politics}

In the Macedonian post-socialist context, the socio-economic devastation brought about by the advent of neoliberalism was compounded by the challenge posed by the country's inter-ethnic relations. At the same time, bilateral identity conflicts with neighbouring states further complicated the international and the internal affairs of the country. The "name dispute" with Greece problematized the country's independence in the 1990s, resulting in an unlawful economic embargo that decimated the economy already crippled by the neoliberal privatization of the 1990s, and sabotaged its efforts to establish itself on the international stage (Cjorgjioska \& Vangeli, 2017). Furthermore, Bulgaria challenged the authenticity of the Macedonian nation, language and history (Engstrom, 2002). Arguably, such external challenges on the Macedonian national identity intensified the need to strengthen it internally. Surrounded by neighbours, which define themselves as ethnically homogeneous states, posed an additional pressure on the Macedonian elites to ascertain their nation-state along similar lines, and at the expense of the country's minorities (Balalovska, 2002). At the same time, the possibility of irredentist claims arising from the concentration of a vast number of ethnic-Albanians in the western parts of Macedonia presented a source of fear and mistrust. In a context circumscribed by internal and regional fears and frustrations, the result was a failure to respond to the demands for protection of the ethnic-Albanian community. The new Constitution labelled ethnic Albanians as a minority group and it deprived them of the right to University education in Albanian, which they had in Yugoslavia (Marko, 2004). Moreover, in 1994, the Constitutional Court overturned a 1985 Yugoslav law requiring respect for the languages of nationalities. On the other hand, anxieties were exacerbated by the Albanian boycott of the Macedonian referendum for independence in September 1991, as well as the illegal referendum in January 1992 in which ethnic-Albanians voted for political and cultural autonomy of the Albanian dominated regions of the country. 'Although the project went no further, suspicions continued to linger that the long-term ethnic Albanian goal is secession and union with a future 
Greater Albania' (Balalovska, 2002) Thus a vicious cycle of fears, frustrations and grievances was unraveling, which resulted in the divergence in the identitarian claims of the representatives of the two largest ethno-national communities in the country - the Macedonian and the Albanian.

Evidently, the precarious post-independence transitional period had both exposed the state to the possibility of an internal conflict and had reduced its ability to resist it. This became apparent in 2001, when following a decade of demands for institutional and legal changes, an armed group transferred the Albanian claims from the political sphere onto the front line. The conflict ended on the 13th of August 2001, with the signing of the OFA. Not only did the Euro-Atlantic community play a role in bringing the Agreement about, it also played a role in its implementation. In view of the crucial intervening role, which both NATO and the EU (and their most powerful member states) have played in these processes, the article analyzes the resulting impact on the implementation of the OFA and its implications on socio-political realities and inter-ethnic relations after 2001.

The Ohrid Framework Agreement as an attempt at complex power sharing

In August 2021 the OFA will mark its 20th anniversary. Signed on the 13th of August 2001, it ended the 8-month-long violent conflict that was waged between the rebels of the National Liberation Army (NLA) and the Macedonian Security Forces. 'Under the Agreement, the Macedonian government pledged to improve the rights of the Albanian population including making the Albanian language an official language and increasing the participation of ethnic Albanians in government institutions, police and army'. ${ }^{3}$ In turn, the leadership of the ethnic-Albanian insurgency agreed to give up any separatist demands and to fully recognize all Macedonian institutions. The OFA has been described as an example of Complex Power-Sharing (CPS), a relatively new integrated concept of conflict regulation, which attempts to incorporate aspects of both consociational and integrative approaches to ethnic conflict regulation (Wolff, 2009, 2011). CPS have been distinguished from other approaches 'in that they no longer depend solely on consociational theory, or solely upon integrative theory, involve and acknowledge international actors as key in designing, or bringing experience to bear upon, the structure of the eventual agreement, or its implementation and seek to address structural issues as diverse as economic management, human and minority rights, doing so at many different levels of government' (Wolff, 2009). Its two novel characteristics are thus a) the emphasis on the key role played by International Actors, and $b$ ) the synthesis between consociationalism and integrationism. Each of these characteristics were ingrained in the OFA and are analysed in turn.

\section{The role of international actors}

The 2001 conflict started in January of that year when the so-called National Liberation Army (NLA) claimed responsibility for three attacks in which four policemen lost their lives. The further evolution of events was characterized by a cycle of violence fueled largely by NLA guerrilla warfare.

3 Framework Agreement (Ohrid Agreement), available at UN Peacemaker https://peacemaker.un.org/fyrom-ohridagreement2001 accessed on 07.05.2021 
The attitude of the Macedonian side from the very beginning was one of conflict management. ${ }^{4}$ Political negotiation was to be considered as an option only after the dismantling of the rebels. It was the role of western international actors (especially the USA and NATO) which instigated the shift from conflict management to conflict settlement, defined as the tactic which seeks to achieve accommodation of the ethnic demands. ${ }^{5}$ In June 2001 NATO intervened to stop a 3 day long offensive by the Macedonian forces in the village of Aracinovo occupied by about 450 members of the NLA, an event which marked the internationalization of the crisis. ${ }^{6}$ Officially, the justification behind the intervention was that the offensive would have led to massive destruction and a deepening of the discontent on the part of the Albanian community. This could have postponed the political dialogue and prolonged the war that could have pushed Macedonia into the chaos and poverty of a prolonged ethnic conflict (Balalovska, 2002). Soon after, at the beginning of July, the mediators in the negotiations suggested a framework document for constitutional and legal changes presented by the French lawyer Badintaire.? The document formed the basis for the OFA, which was signed on the 13th of August 2001.

In line with the key tenets of complex power sharing, "(western) international actors played a key role in paving the way towards the OFA, as well as in designing its structure". Their role was also crucial in its implementation. Early in the process of the OFA the EU conditioned some of its aid for Macedonia on the implementation of the constitutional amendments that derived from the OFA. ${ }^{8}$ The EU's 'carrot' for securing the compromises entailed in the OFA was the prospect of EU membership for Macedonia (Daskalovski, 2004). Each step in the further progress towards accession was linked to progress on interethnic relations, and other reforms in rule of law, effective administration and judiciary. In December 2005, when Macedonia gained candidate country status, the progress with the implementation of the OFA was highlighted by the EU as the main reason. Since 2006, the EC progress reports (in which Macedonia has been evaluated as a candidate country), have evaluated minority rights and the implementation of the OFA as the

\footnotetext{
4 Conflict management is an attempt to contain, limit, or direct the effects of an ongoing ethnic conflict on the wider society in which it takes place. (Wolff 2004:12). It represents a range of strategies chosen instead of negotiation, which is avoided because the settlement is either impossible or undesirable for one of the parties involved. The preferred alternative policies can include anything from ethnic expulsions to hegemonic control.

5 Conflict settlement's goal is to establish 'an institutional framework in which the conflicting interests of different ethnic groups can be accommodated to such an extent that incentives for cooperation and the non-violent pursuit of conflicts of interests outweigh any benefits that might be expected from violent confrontation.' Therefore, it seeks to ideally achieve accommodation (in the form of integrationism or consociationalism) of all ethnic and territorial claims. (Wolff, 2004:12)

6 At the same time Brussels made it clear that the Stabilization and Association agreement would be frozen and the funds from the Stability Pact cancelled if this did not happen.

7 The document set several basic principles: the use of violence for the achievement of political goals was completely and unconditionally rejected; the sovereignty and territorial integrity and the unity of Macedonia were guaranteed, the multiethnic character of the state was to be reflected in the public life and institutions; the development of a decentralized government, equal participation of the national communities in public administration; the right to veto for minorities in affairs regarding cultural and linguistic interests.

8 Also, in order to sustain its involvement in the conflict management in Macedonia, the EU in 2001 established the post of a Special Representative under the umbrella of the HR for CFSP
} 
key priorities for the EU under the political criteria. Nevertheless, the precise implications of the international influence on the OFA and the broader inter-ethnic relations, can only be tackled by examining the extent by which the Agreement has been (un)able to synthesize its consociational and integrationist principles, as the second key feature of complex power sharing agreements.

\section{Consociational and integrationist tenets of the OFA}

Consociationalism considers ethnic conflict to be an upshot of competing elites' instrumentalisation of ethnic and national identities. Accordingly, consociational strategy emphasizes the 'presence of strong political elites willing to accommodate each other and capable of winning their followers' support for the resulting bargain', as the key to the viability of democratic stability in segmented societies (McGarry\&O'Leary, 2003: 3). Lijphart proposed that elite cooperation should be accompanied by the following institutional framework: 1) government by a grand coalition of the political leaders of all significant segments of the plural society 2) mutual veto or 'concurrent majority' rule, which serves as an additional protection of vital minority interests 3) proportionality as the principle standard of political representation, civil service appointments, and allocation of public funds 4) a high degree of autonomy for each segments to run its own internal affairs (Lijphart, 1977: 25). Consociationalism rejects the contention that due to a lack of cross-cutting cleavages, instability is to be expected in culturally heterogeneous societies. Instead of abolishing or weakening segmental cleavages, it aims to recognize them explicitly regardless of the social fragmentation this can cause (Lijphart 1977: 42).

Integrationism criticizes the consociational model for its focus on conflict-settlement as 'elite-initiated'. Rooted in a constructivist understanding of ethnicity, this approach is sceptical about the trustworthiness of the elites. It argues that "there is no reason to think automatically that elites will use their leadership position to reduce rather than pursue conflict' (Horowitz 1991:141). Instead, it places the focus on the mass/societal level and the need to resolve the deep roots of inter-ethnic divisions and conflicts. Integrationism is thus focused on the methods which political institutions should employ in order to stimulate or induce integration across communal divides as the best way towards conflict resolution. Incentives for moderation are encouraged so that politicians can appeal beyond their own communal segments for support. The mechanisms proposed in order to encourage integration across communal divides are: 1) dispersion of power, which proliferate points of power so as to take the heat off of a single focal point; 2) devolution of power and reservation of offices on an ethnic basis in an effort to foster intra-ethnic competition at the local level; 3 ) inducements for interethnic cooperation, such as electoral laws that effectively promote pre-election electoral coalitions through vote pooling; 4) policies to encourage alternative social alignments, such as social class or territory, by placing political emphasis on cross cutting cleavages; and 5) reducing disparities between groups through managed distribution of resources. (Horowitz 1993: 36)

Complex power-sharing attempts to incorporate integrationism and consociationalism, into a single comprehensive theory approach. The synthesis between the two is viewed as providing a better means towards sustainable conflict resolution, which is considered to be the most ambitious 


\section{Seceururity}

of all the conflict regulating mechanisms. This is due to its attempt to identify the causal factors fundamental to the conflict and to develop the means to address them effectively by addressing both the elite and the societal level (Schneckener \& Wolff, 2004). ${ }^{9}$ The OFA established a power sharing system whose constitutional amendments adopted principles, institutions and policies, which in theory represented a synthesis of consociational and integrationist mechanisms. The minority veto and the proportional electoral system and representation are characteristically consociational. At the same time, the Agreement allows sufficient scope for integrationism. There is no formalized agreement for a Grand Coalition, although there is an implicit requirement to include an Albanian party in the governing coalitions. This was arguably an attempt to prevent the institutionalization of ethnicity by allowing the emergence of alternative social alignments, such as social class, as the basis for political mobilization. In addition, there was a provision for the development of decentralized governance, a manifestly integrationist mechanism. However, in the years post-2001, against the backdrop and under the influence of ethnic identity (geo) politics, these integrationist aspects were increasingly undermined at the expense of elite-level consociational bargains, which were frequently endorsed by the western international actors involved in the process.

\section{Coalition Building}

The absence of a Grand Coalition in the OFA can be interpreted as an attempt to encourage integrationism, allowing space for coalitions formed along ideological rather than ethnic lines. According to the OFA, the state is unitary, and the government is formed by whoever manages to collect at least 61 mandates. There is no stipulation for a Grand Coalition, which in consociational terms would require the inclusion of a particular ethnic-Albanian party. Nonetheless such possibilities presented by the OFA have failed to lead to integrationist practice. This became apparent following the Parliamentary Elections in 2006, when DUI (the party formed out of the ranks of the NLA) which had been in power since 2001, was not asked to join the governing coalition, in spite of winning the majority of the Albanian votes. VMRO-DPMNE, which won the majority of the votes, instead chose to form a coalition with the DPA. This resulted in strong resistance from DUI, whose leaders oscillated between threatening renewed ethnic conflict, boycotting parliamentary sessions and putting up a new list of minority demands. Under significant western pressure, VMRO-DPMNE finally agreed to sit on the table and to negotiate an agreement with DUI. In the years that followed, DUI made sure that the Grand Coalition would become established as the customary norm in coalition building, although it was not postulated as such in the OFA. As a result, with the brief exception of the period 2006-2008, DUI has been in Government continuously since 2002. Throughout this period, it campaigned exclusively on an ethnic platform, which influenced the ethnicization of the broader political scene. In the process, ethnicity has become established as both a shield and an instrument used for shifting the lines of division from the

\footnotetext{
9 The other two conflict regulation mechanisms are conflict management and conflict settlement.
} 
domain of accountability for criminal political and social injustice to the domain of ethnic identity politics and nationalism (Gjorjgioska, 2017).

\section{Decentralisation}

The OFA provision for the development of decentralized governance can be interpreted as an integrationist mechanism aimed at fostering intra-ethnic competition and inter-ethnic vote pooling on the local level (Horowitz, 2003). However, its implementation in practice created disincentives for integration across communal divides. The new Law on Territorial Organization in 2004 revised municipal boundaries in such ways that more new municipalities with an ethnic Albanian majority were created. Since the borders were not based on administrative or geographic criteria, their sole purpose seemed to be the creation of municipalities where ethnic Albanians would comprise more than $20 \%$, thereby enabling the exploitation of the special provisions of the OFA. As a result, the overall process has been characterised as 'ethnic gerrymandering'. The leaders of the coalition parties openly admitted that the territorial reorganization of the municipalities was driven by the ethnic principle, although this ran contrary to the basic principle of the OFA- that 'there are no territorial solutions to ethnic questions'. In opposition to these changes, the Citizens' Movement for Macedonia mobilized well-known figures from the intelligentsia, business elites and civil society in an effort to support a referendum against the changes. In addition, the World Macedonian Congress, a pan-Macedonian diaspora organization, organized the collection of 150,000 signatures in order to test these municipal border revisions on a nationwide referendum. The EU and the USA pressured the Government not to prolong the process of decentralization despite the public opposition. The EU was 'worried by a possible successful referendum', while the USA considered that the referendum was a 'clear step backwards' (Maleska, 2006). Although the western international actors strongly and openly backed the position of the government, polls constantly showed that the referendum result would reject the boundary revisions. However, on 4 November 2004, just 3 days before the referendum, the USA made the official decision to recognize Macedonia under its constitutional name. Many connected the failure of the referendum with the recognition by the USA, thus assigning a clear interventionist role to the United States in the implementation of decentralisation characterised with pronounced gerrymandering features. At the same time, the recognition demonstrated an instance of "ethnic identity (geo)-politics" as it demonstrated the interaction between internal and bilateral identity politics under the influence of international actors.

The referendum, held on 7 November 2004, failed because of the low turnout of $26.58 \%$. The territorial reorganization led to two significant changes. Firstly, as a result of the redrawn boundaries the Macedonians found themselves in a minority in several municipalities. Secondly, members of local communities, especially in ethnically homogeneous municipalities, have remained enclosed within their own municipal borders. The most adverse consequence, however, has been the intensification of suspicions in ethnic Macedonian circles that the decentralization is a step towards territorial independence, federation or secession. What is more, the communal unrests, which followed, showed that even when the elites of the different communities cooperate on 
certain policies, they may not be able to mobilize or draw the masses in support of their decisions. In turn, this indicates the potential of the masses to disturb the peace even when there is cooperation on the elite level, thus demonstrating the limitations of a purely consociational approach in achieving sustainable conflict resolution.

\section{OFA language provisions}

The establishment of a common (civic) nationality is considered to be a crucial precondition for the sustaining of a political entity over a long period of time. As trust is one of the prerequisites for the sustenance of a community, the minimum required for developing a shared understanding among peoples is a common medium of communication. The role of having one official language in linking members of various ethno-cultural groups is thus considered to be indispensable (Daskalovski, p. 7). The OFA provisions, which regulate community languages, have decreased the space for the development of such a sense of community in the Republic of Macedonia.

Based on the provisions of the OFA, the Language Law was adopted in July 2008, regulating the use of the community languages in several areas. ${ }^{10}$ At the local level, it was decided that in municipalities where over $20 \%$ of the inhabitants speak a given language, they may use it in communication with representatives of the local and central institutions. Moreover, with the opening of two Universities in Albanian, less and less Albanians enrolled in courses taught in Macedonian, resulting in the increase in the number of Albanian students with poor knowledge of Macedonian. In primary education, the division of schools and classes between those taught in Macedonian and those taught in Albanian continued the segregation. According to the Advisory Committee on the Framework Convention for the Protection of National Minorities, Albanian students' education in the Macedonian language is insufficient to gain proficiency. ${ }^{11}$ Combined with the limited opportunities for Albanian students to use and practice their Macedonian-language skills, the obvious consequence is that, less and less Albanians speak good Macedonian and are familiar with their compatriots, which in the long run is likely to reinforce mutual stereotypes and prejudices. ${ }^{12}$

10 In the Assembly (Article 3), in citizen communication with the ministries (Articles 4 and 18 (2)), in judicial proceedings (Articles 5-14), in the judicial institutions (Articles 15 and 17), in the general administrative procedure (Article 18), in execution of sanctions (Article 19), by the ombudsman (Article 20), in the electoral process and the forms of direct democracy (Articles 21-28), in personal documents (Articles 29-30), in civil registries (Article 31), by the police authorities (Article 32), in broadcasting services (Articles 33-39), in the name of streets, squares, bridges and other infrastructure objects (Articles 40), by the local self-government (Articles 41-43), in financial and economic activities (Articles 44-47), in education and science (Articles 48-53), in cultural activities (Articles 54-56), in the process of free access to public information (Article 57), and in the publishing of legal acts (Article 58).

11 Ethnic Albanians commence the study of the Macedonian language only in the third grade, for two hours per week, and as of the sixth grade for three hours per week / Fourth Report Submitted by "FYROM" pursuant to art 25, Paragraph 2 of the Framework Convention for the Protection of National Minorities, available at https://rm.coe.int/ CoERMPublic CommonSearchServices/DisplayDCTMContent?documentld=09000016800902e5

12 In 2003, Education Minister, Aziz Pollozhani (DUI), tried to launch pilot attempts at reintroducing ethnic mixity in three schools located in Skopje (Čair), Kumanovo and Bitola, but his policy met with intense opposition from parents, students' unions, teachers and local residents alike. To this day in many instances local actors still prefer to see pupils 
In 2018, the Law on the Use of Languages replaced the 2008 Language Law. ${ }^{13}$ Several of its key shortcomings have been emphasized by the Venice Commission - as part of its legal opinion adopted in December 2019.14 Taken as a whole, the comments are illustrative of the continued influence of consociational elite bargaining as the predominant organising principle of inter-ethnic relations post-2001. The first set of comments relates to the extension on the use of the Albanian language, which the 2018 Language Law extends to all Albanian speaking citizens regardless of their place of residence. It encompasses central institutions, public enterprises, agencies, directorates, as well as the laws, bylaws and decisions of these organs. Moreover, it covers anything from civil registries and postal stamps, to fiscal reports, infrastructural designations and banknotes. The Venice Commission noted that such an extension of bilingualism is extremely broad and several of its articles go beyond the standards of minority protection laid down in European and international documents. Moreover, it found that the "new Law appears to be very complicated". Given the financial constraints and the insufficient number of interpreters and bilingual staff currently available the Commission expressed "doubts about the capacity of the central institutions to implement all provisions of the Language Law" as well as the "current situation in terms of finance, staff and training possibilities for the enforcement of their legal obligations regarding the use of the community languages".

Furthermore, the Commission has problematized the Law's use of the words "shall" and "will", as exemplified in Articles 4 of the Law, which state that "a member of Parliament, speaking a language other than Macedonian which is spoken by at least $20 \%$ of the citizens (that is, Albanian language) "shall" speak in that language". According to the Commission "the imposition of the use of Albanian or any other community languages on individuals constitutes a violation of the right to freedom of expression and the right to free self-identification".

The third set of criticisms pertains to the shortened parliamentary procedure used to pass the new Law. ${ }^{15}$ According to the Rules of procedure of the Assembly, a draft law may be adopted with a shortened procedure if it is a "non-complex or non-extensive" draft law of harmonisation

from diverse ethnic backgrounds attend classes in separate shifts or even in separate buildings (Maleska, 2003:43). At moments when local tensions were high, this policy probably helped to avoid local clashes and to reassure local communities.

13 Law on the use of languages spoken by at least $20 \%$ of the citizens of Macedonia and in the units of local self-government

14 North Macedonia Opinion on the Law on the Use of Languages, Adopted by the Venice Commission, at its 121st Plenary Session (Venice, 6-7 December 2019) available at https://www.venice.coe.int/webforms/documents/default. aspx?pdffile=CDL-AD(2019)033-e

${ }_{15}$ Harmonisation of the legislation of the Republic of Macedonia with the EU acquis communautaire is a process of approximation of the solutions in the national legislation to the EU law. Harmonisation and unification of the law in the EU should enable creation of a single area of freedom, security and justice, and a single market with unobstructed exercise of economic and other functions of the Union. The obligation for harmonisation of the legislation of the Republic of Macedonia with the EU acquis has been incorporated in Article 68 of the Stabilisation and Association Agreement. The new Rules of Procedure of the Assembly of the Republic of Macedonia, in its Article 135 stipulate that the draft laws harmonising our legislation with the EU acquis should contain information relating to the original acts of the European Union with their full title, number and date along with a statement on the harmonisation status. Once these laws enter parliamentary procedure, they are given European flag indication distinguishing them from the other acts. 
with the EU legislation. This legal mechanism has been frequently (ab)used in the passing of ethnic laws (such as the Law on Decentralisation) although they are not related to the process of harmonisation and unification with the law of the EU. This was the case also with the 2018 Law on Languages. As a result, the draft law was examined by the Committee on European Affairs instead of the Committee on Political System and Relations among the Communities, which had only three working days to discuss the amendment proposals. Consequently, only a few out of around 80 amendment proposals made by the opposition were discussed before the Committee. The votes on the Language Law on 11 January and 14 March 2018 were held in the absence of the members of Parliament of the largest opposition party VMRO-DPMNE and without debating their amendment proposals, which raised fierce public reactions followed by demonstrations. The Commission concluded that "it is regrettable that a law entailing such a major, and politically sensitive, reform of language policy was passed in such a manner". Moreover, in the opinion of the Commission, a broad and inclusive consultation could have improved the material quality of the Language Law, enhanced its legitimacy and made it easier to enforce. In view of the above, through the dismantling of the possibility of a common language as one of the principles of community building, it can be argued that the OFA has diminished another of the integrationist principles of cross-ethnic understanding and stability.

\section{Complex power sharing in the context of EU and NATO accession}

Following Macedonia's declaration of independence in 1991, integration in NATO and the EU were portrayed as the country's priorities in foreign policy. A broad consensus was built around the desirability of membership. The legitimation process of both the EU and NATO entailed their presentation in public discourse as almost automatic guarantors of stability and prosperity. What is more, the Macedonian society was not excluded from the range of mechanisms of legitimation described by Kuus (2009), which were set in motion since the early 1990's, and which aimed to project the image of NATO as "a kind of United Nations in military uniform". On a discursive level, the framing employed phrases such as "Euroatlantic values of freedom and security", "cooperation and security", "just and lasting democracy", "human rights" and "the rule of law", in order to reconfigure, normalize and normatively legitimize the NATO alliance (Kuus, 2009). It is in this context that the frequently reported high desirability of NATO and EU membership must be viewed as an extension of the mechanisms of legitimization, which serve to create rather than track public opinion. ${ }^{16}$

At the same time however, (ethno-national) identity politics played additional roles in legitimizing the accession into the EU and NATO. On the one hand, EU and NATO membership was associated strongly with the country's self-colonising quest to prove its value as a worthy member of the European and Western civilization. What is more, the legitimation process also

16 The International Republic Institute has reported NATO's support rate to be $92 \%$ in $2008,73 \%$ in $2016,77 \%$ in 2018; and support for the EU to be $83 \%$ in 2018 "IRI High support for EU and NAT0, ahead of the referendum" "ИРИ: Висока поддршка за ЕУ и НАТО, спроти референдумот", 29.08.2018, available at https://mk.voanews.com/a/ iri-poll-macedonia-/4548832.html accessed on 01.02.2021 
took on an (inter-)ethnic identitarian dimension. The Macedonian political elites claimed that the unity and security of the Macedonian state would be guaranteed once membership is achieved. On the other hand, the Albanian political elites felt that the resolution of external pressures will indirectly lead to the strengthening of their ethnic identity, as the state will become a member of EU and NATO, where ethnic Albanians will no longer be divided by state borders (Leka, 2020). The inter-ethnic relations between the Macedonian and Albanian ethnic communities also became entangled in and contributed to such legitimations of the NATO Alliance (and the EU): "the society deeply divided along ethnic/religious/language lines sees NATO (and EU for the same reason) as a glue to keep society together" (Vankovska, 2017, p.6). As political elites frequently portrayed integration in NATO and the EU as a factor of inter-ethnic cohesion in the mainstream discourse, the legitimation of EU and NATO was characterised by the interaction of identity politics with geopolitics.

Discussions over the concrete socio-economic implications that would follow from the geopolitical and economic integration in these structures was largely absent or completely marginalized. This can be seen as one of the results of the complete discrediting of the politics of redistribution under the ideological influence of neoliberalism, which aimed to distance the society as further as possible from its socialist history and legacy. In the absence of class-based politics, the socio-economic implications of the country's integration in the Euro-Atlantic structures remained obscured and disregarded at the expense of identity politics. As a result, public discourse was markedly superficial and lacking in discussions about the real socio-economic and geopolitical implications of the Macedonian integration in these neoliberal structures. ${ }^{17}$

\section{Ethnic-identity (geo)politics as a zero-sum game}

The frictions caused by ethnic identity (geo-)politics became evident in the period post 2008, when Macedonia's bilateral identity issues with first Greece and then also Bulgaria started to influence the accession processes to the EU and NATO. The country's inter-ethnic relations both influenced and were influenced by these processes, primarily because the two largest ethnic groups were not affected equally by the disputes (Vankovska 2017).

In April 2008, at the NAT0 summit in Bucharest, Greece presented the case for its veto on Macedonia's accession to the Alliance. The official reason given was the failure to reach a solution in the name dispute (Gjorgjioska, 2020). Immediately after this development, ethnic Albanian party-leaders Thaci (DPA) and Ahmeti (DUI) stressed the importance of resolving the name dispute with Greece as the key to ensuring Macedonia received a NATO membership invitation. What's more, both "predicted significant inter-ethnic conflict if Macedonia fails to receive a NATO invitation". ${ }^{18}$ In 2018, Bujar Osmani, former minister of European affairs and current Minister

\footnotetext{
17 One exception to the rule was the emergence of the political party Levica in 2015, which campaigned on a social justice/socialist platform, informed by anti-imperialist and anti-neoliberal principles. Political platform avaiable at www.levica.mk

18 "Ethnic Albanian Leaders on NATO and the Name Issue", 12 March 2008, at <https://wikileaks.org/plusd/cables/08SKOPJE194_a.html>
} 
of Foreign Affairs from DUI emphasized: "There is no more significant ethnic interest for the Albanians than the membership of Macedonia in NATO. ${ }^{19}$

At the same time, whilst the Macedonian ethno-national identity was threatened by the Greek and Bulgarian conditionality, the Albanian political elites didn't share their concerns: "If you look at foreign policy, all of its problems, they are problems of the ethnic Macedonians, not of all ethnicities" (Leka, 2021). Since the Albanian ethnic identity was unaffected by the Greek (and Bulgarian) demands, the Albanian elites began placing pressure on accepting a compromise with the two neighbors.

Conversly, Macedonian political elites were naturally predisposed to a more cautious approach in relation to these bilateral disputes, as they primarily concerned the ethno-national Macedonian identity (Leka, 2021). This is also reflected in the opinion polls. In 2018, 59.6\% of ethnic Macedonians stated they are against any change to the name of the country, while only $6.6 \%$ of ethnic Albanians reported to be against any change to the name. Inversely, only $4.7 \%$ of Macedonians are in favor of a new "erga omnes" name, while $42.3 \%$ of Albanians are in favor of this option (Klekovski et al, 2018). ${ }^{20}$ Consequently, the Albanian political factor has carried out several separate diplomatic offensives in pursuit of the "unblocking of the international integration agenda of the state" (Leka, 2020). These in turn caused further division and mistrust internally amongst the Macedonians who considered such behaviors as disregardful of the 'national interests' and as detrimental to the inter-ethnic trust and cohabitation (Vankovska, 2017).

As a consequence of these pressures, the supposed cross-ethnic integrative function of the EU and NATO (however strong it may have realistically been previously) started to rapidly fade after 2008. The accession process thus began to acquire the character of an inter-ethnic zero-sum game.

\section{Inter-ethnic (geo-)-politics and the Prespa Agreement}

In June 2017, a new Government was in place for the first time in over a decade. During his first official visit to Brussels as Prime Minister, Zoran Zaev announced the course of the SDSMDUI coalition Government: "In foreign policy our priorities will be to revive our integration in the European Union and the NATO alliance, but also to be as good a neighbour as possible". ${ }^{21}$ The Government thus embarked on resolving the bilateral issues with both Bulgaria and Greece.

Following a year of negotiations, the Prespa Agreement was signed in June 2018. According to it, the Republic of Macedonia was to be renamed the Republic of North Macedonia. In addition to the country's name change, the Agreement included severe interventions in the country's

\footnotetext{
19 "Osmani: Sending a message that they put a break on membership to nato is the worst service you can do to Albanians", mkd, 8 January 2019, at <https://www.mkd.mk/makedonija/politika/osmani-isprakjanjeto-poraka-deka-se-kochnichari-na-chlenstvoto-vonato-e $>$.

20 According to polls conducted in 2010-2017, when citizens were asked to choose between: EU and NATO or preserving the constitutional name, a significant ethnic divide appeared. Hence about $64,9 \%$ of ethnic Macedonians were pro preserving the name, while $68 \%$ of ethnic Albanians were pro EU and NATO (IDSCS and MCMC 2014, p.19) 21 Transcript of the Press Statement by Minister of Foreign Affairs Dimitrov, given in Athens June 2017, at <http:// mfa.gov.mk/index.php?option=com_content\&view=article\&id=229 9:poseta-na-ministerot-za-nadvoreshni-raboti-nikola-dimitrov-na-grcija \&catid $=52 \&$ lte mid=684\&lang=mk $>$.
} 
constitution, passports and history books with far-reaching consequences over issues of ethnic identity and national self-determination (Gjorgjioska, 2020). In return it was agreed that Greece would unblock the country's accession to NATO. The Agreement's ratification process involved two steps: a referendum and the passing of constitutional changes.

The referendum on the name change was held in September 2018 and it presented a clear linkage of the accession processes with the name issue by posing the following question: "Are you in favour of European Union and NATO membership by accepting the Agreement between the Republic of Macedonia and the Republic of Greece?" In spite of the widespread campaign supported by leaders from the most powerful EU and NATO member-states, the Referendum achieved a turn-out of only $36.89 \%$ participation and it failed. ${ }^{22}$ Nonetheless, in spite of the lack of popular approval, the Prespa Agreement was pushed through Parliament under a process which has warranted ample criticism. Namely, the MP votes to rename Macedonia into North Macedonia, were used as leverage for impunity and selective amnesty for public officials accused of severe abuses of office. (Gjorgjioska, 2020). In spite of this, the process was supported and endorsed by the leaders from the EU, NATO and their member states. ${ }^{23}$ Following this process, on 14 February 2019, the new name - Republic of North Macedonia, entered into force.

Unsurprisingly, the devastating blow which this turn of events has had on the Macedonian national identity has contributed to the diminishing support of Macedonians for the EU and NATO agenda (Leka, 2021). The support for the EU fell from 80\% in 2014 to $65 \%$ in 2019. At the same time the Eurosceptics rose from $14 \%$ in 2014 to $19 \%$ in 2019. With regards to the importance attached to the EU membership, there has been a significant ethnic disparity. Whilst $20 \%$ of Macedonians consider EU membership to not be important at all, only $8 \%$ of Albanians feel the same. Moreover, Macedonians are more sceptical than Albanians about the membership becoming reality (with 30\%) compared to $9 \%$ ethnic Albanians (Damjanovski, 2020).

Such surveys combined with the result of the failed referendum paint a different picture with regards to the support for EU and NATO membership to the one that has long been presented in the mainstream discourse. At the same time, they demonstrate that the perceptions of the ethnic-Macedonian public are at odds with the perceptions held by the political elites from the two largest Macedonian political parties (SDSM and VMRO-DPMNE). In interviews with high-ranking representatives from the two parties, Leka found that their foreign policy preferences or orientations are almost identical and haven't changed or diversified under the external pressures on national identity post-2008 (Leka, 2020). This can be interpreted as a mismatch in the foreign policy objectives of the political elites and the masses, which can only intensify in the context of a possible unpopular resolution of the bilateral dispute with Bulgaria.

22 Out of the 609,427 individuals who voted in favour of the Agreement, 260,000 are thought to have been ethnic Albanians, "Over 260,000 Albanians in Macedonia Vote in Referendum in Favor of the Agreement", Oculus News, 1 October 2018, at <https://www.ocnal.com/2018/10/over-260000-albaniansin-macedonia-vote.html>.

23 https://mk.usembassy.gov/macedonias-referendum-on-the-prespa-agreement/ 


\section{Seceururity}

\section{Inter-ethnic (geo)-politics and the dispute with Bulgaria}

In July 2017, the Treaty on Friendship, Good Neighbourliness and Cooperation was signed between Bulgaria and Macedonia. Although it aimed to pre-empt a potential Bulgarian veto to the Macedonian EU accession pathway, the Agreement failed to produce the intended effect. On the 17th of November, Bulgaria vetoed the opening of EU accession negotiations with Macedonia. Arguably, Bulgaria has followed in Greece's footsteps and had adopted its approach - by instrumentalizing the internal ethnic divisions, in a zero-sum fashion, it has imposed its aggressive maximalist version of history on Macedonia, in exchange for lifting its veto in the EU. The EU has failed to prevent the Bulgarian veto or its imposition of conditionality on the Macedonian accession process. Internally, these developments have sparked a chain of events, which culminated with wide-spread social outrage against the Government's positioning on the issue. Numerous institutions, public intellectuals, current and former officials criticized the overall approach of the Government, describing it as overly conciliatory, damaging and disrespectful for the position of the country and its history in view of the Bulgarian government's negationism of Macedonian language, identity and (anti-fascist) history. Most importantly however, the social outrage revealed the big and widening gap between the ruling political elite and the positions espoused by the people they claim to represent (Gjorgjioska, 2020).

Whilst Zaev demonstrated a readiness to appease Bulgarian aggression by accepting the Bulgarian nationalist "version of history", the big social backlash suggested that the Macedonians are not willing to sacrifice their history and national dignity in exchange for the vague promise of EU membership. In view of this, it is to be expected that the desirability of EU membership is likely to continue to fall amongst ethnic Macedonians potentially causing further divergences with the positions espoused by the Macedonian and Albanian political elites.

\section{Conclusion}

Situating the country's inter-ethnic relations at the intersection of internal and international relations and processes, the article has analysed the influence of two strongly interrelated processes: Macedonia's neoliberal transformation and its accession to the EU and NATO. It has been argued that the OFA represents both a product of and a contributor towards the establishment of ethnic identity politics as a hegemonic organising principle of Macedonian socio-political relations. The phrase "ethnic identity (geo)politics" has thus been used as an umbrella term to describe the complex interaction between inter-ethnic relations at the intersection of the ideological and geo-political influences of neoliberalism and Euro-Atlanticism. The analysis of its long-term repercussions in the Macedonian context has demonstrated the entrenchment of consociationalism at the expense of integrationism.

The compounded effect of these structures and processes has been to strengthen and enhance the role of ethnic identities at the expense of all others. As rights have been rewarded primarily on the basis of ethnicity, this has served to legitimize ethnic affiliation as the most valid claimant of rights and to escalate demands for special ethnic rights. This has led to an ethnicization of the society, whereby even issues which are not ethnic are defined as such, because of a per- 
ceived benefit from doing so. Perceptions that ethnic identification serves only for the purpose of advancing self-interests has further aggravated societal suspicions, resentments and discord. Combined with the ideological influence of neoliberalism, this has meant that alternative affiliations and identifications have been relegated to a marginal position. The context delineated in this manner has eroded the possibility of a cross-ethnic (national) line being adopted in relation to membership in NATO and the EU, and the challenges posed by regional identity politics. Once membership became challenged by Greek and Bulgarian identity claims, inter-ethnic relations in the country have turned into a zero-sum game. Previously presented as an inter-ethnic glue, in the context of these bilateral disputes, the EU and NATO accession processes have multiplied the inter-ethnic dissensus. The main reason for this has been its focus on the elite level in line with consociational logic whereby stability has been drawn from temporary inter-elite bargains, with no regard to the societal frictions which this produces.

Since good inter-communal relations are crucial for societal stability, these trajectories have set the Macedonian society on a very unstable path for the future. In the absence of inter-communal civic engagement, very few pressures for stability exist. Conversely, there is ample space for popular dissatisfaction with inter-elite compromise. What is more, the reliance on elite-level bargains gives them a free hand in polarising the population. At the same time the society has very few mechanisms to prevent or disrupt politicians' use of polarising strategies or in defusing polarising strategies when they are adopted (Varshney, 2002).

Western international actors (most prominently the EU, NATO and their most powerful member states) have played a crucial intervening role in the establishment of these structures and tendencies. Firstly, they played a decisive role in bringing about the Ohrid Framework Agreement and in its different phases of implementation. In the post-2001 period, through a combination of direct interventionism, pressures on political elites and tacit approval, they have played a decisive role in the entrenchment of consociational principles at the expense of the Agreement's integrationist tenets, which have been completely undermined and disregarded in practice. In view of their sustained and continuous influence, their contribution must not be overlooked when assessing the long-term consequences of what has here been described as "ethnic identity (geo) politics". Thus, contrary to the view, which has ascribed the role of an integrationist cross-ethnic glue to the neoliberal transformation and the NATO and EU accession processes, it has been concluded that these have in fact contributed to the furthering of inter-ethnic divisions and the erosion of sustainable conflict resolution in the country.

\section{References}

1. Augoustinos, M., \& Walker, I. (1995). Social cognition. London, UK: Sage Publications.

2. Balalovska, K. (2002). A historical background to the Macedonian-Albanian inter-ethnic conflict, New Balkan Politics, 3-4 available at http://www.newbalkanpolitics.org.mk/ item/A-Historical-Background-to-the-Macedonian-Albanian-Inter-Ethnic-Conflict\#. YJI6BSORqTd 
3. IPRS. (2018, November). Истражување на ИПИС за перцепцијата на граѓаните за односите со Грција и перцепции за ЕУ и НАTO [Research of IPRS on citizen's perceptions on the relations with Greece and EU and NATO]. Accessed on 10.05.2021, available at https://ipis.org.mk/wp-content/uploads/2019/01/Percepcii-za-aktuelni-politicki-prasanjall-del_Fev-2018.pdf

4. Damjanovski, I. (2020). Analysis of public opinion on North Macedonia 's accession to the European Union (2014-2019). Accessed on 05.04.2021, Availablet at https://idscs.org. mk/wpcontent/uploads/2020/02/A5_Analysis-of-public-opinion-onNorth-Macedoniasaccession-tothe-European-Union-2014-2019ENG.pdf

5. Daskalovski, Z. (2002). Language and Identity: The Ohrid Framework Agreement and Liberal notions of Citizenship and nationality in Macedonia, Journal of Ethnopolitics and Minority issues in Europe

6. Daskalovski, Z. (2004). Democratic consolidation and the 'stateness' problem: The case of Macedonia. Global Review of Ethnopolitics, 3(2), 52-66. https://doi. org/10.1080/14718800408405165

7. Engström, J. (2002). "The power of perception: The impact of the Macedonian question on intep-ethnic relations in the Republic of Macedonia". Global Review of Ethnopolitics, 1(3), 3-17. https://doi.org/10.1080/14718800208405102.

8. Cjorgjioska, M.A (2017). "Nationalism at the rescue of Macedonia's criminal elites", LeftEast, https://lefteast.org/nationalism-at-the-rescue-of-macedonias-criminal-elite/

9. Cjorgjioska, M.A. (2020). "Ethnicity and Nationality in and around the 'Prespa Agreement on the Macedonia Name Issue", European Yearbook of Minority Issues Online, 17(1), 190-211. doi: https://doi.org/10.1163/22116117_01701009

10. Gjorgjioska, M.A. (2020). “Prime Minister Zaev sparks social outrage following Bulgaria's veto to Macedonian EU accession negotiations", China CEE Institute, Vol. 34, No. 3 (MK) November 2020, available at https://china-cee.eu/wp-content/uploads/2020/12/2020s11_ North-Macedonia.pdf

11. Harvey, D. (2005). A brief history of neoliberalism. Oxford, UK: Oxford University Press

12. Horowitz, D. L., (1985). Ethnic Groups in Conflict. Amsterdam, Netherlands: Amsterdam University Press.

13. Heraclides, A. (2020), "The settlement of the Greek-Macedonian naming dispute: the Prespa agreement", Security Dialogues, 11(1).

14. Horowitz, D. (1998). Structure and Strategy in Ethnic Conflict. Presented at the Annual World Bank Conference on Development Economics, Washington, D.C.

15. Horowitz, D. L. (1993) Democracy in Divided Societies, Journal of Democracy, vol. 4: 4, 18-38.

16. Horowitz, D. L. (2003) Electoral Systems and Their Goals: A Primer for Decision-Makers, Journal of Democracy, vol. 14, no. 4 (October 2003), 115-27.

17. Klekovski, S., Mihailovska, J., \& Jovanov, M. (2018). The Name Dispute. Skopje: Macedonian Center for International Cooperation (MCIC); Institute for Democracy (IDSCS).

18. Leka, G. (2020). External Influence over Foreign policy and inter-ethnic relations: The case of Republic of North Macedonia, PhD Thesis, available at https://repository.ukim.mk/ bitstream/20.500.12188/9921/2/gleka2021eng.pdf

19. Lijphart, A. (1969). Consociational Democracy. World Politics, 21(2), 207-225. 
20. Lijphart, A. (1977). "Majority rule versus democracy in deeply divided societies". Politikon, 4(2), 113-126.

21. Lijphart, A. (2008). Thinking about democracy: Power Sharing and majority rule in theory and practice, Routledge.

22. Maleska, M. (2005). What kind of a political system did Macedonia get after the Ohrid Peace Agreement, New Balkan Politics, 9(3).

23. Marko, J. (2004). "The Referendum on Decentralization in Macedonia in 2004: A Litmus Test for Macedonia's Interethnic Relations", European Yearbook of Minority Issues Online, 4(1), 695-721. doi: https://doi.org/10.1163/22116117-90000031

24. Mc Garry, J. and O'Leary, B. (2006). "Consociational Theory, Northern Ireland's Conflict, and its Agreement", Government and Opposition, 41(2): 249-277.

25. Wolff, S. (2004). "Managing and Settling Ethnic Conflicts". In Ulrich Schneckener and Stefan Wolff (eds.) Managing and Settling Ethnic Conflicts: Perspectives on Successes and Failures in Europe, Africa and Asia, Palgrave MacMillan.

26. Wolff, S. (2008). "Complex Power Sharing as Conflict Resolution: South Tyrol in Comparative Perspective". In J. Woelk, F. Palermo, and J. Marko (eds.). Tolerance through Law: Self-governance and Group Rights in South Tyrol. Leiden and Boston: Martinus Nijhoff, 329-370.

27. Wolff, S. (2009). "Complex Power-sharing and the Centrality of Territorial Self-governance in Contemporary Conflict Settlements", Ethnopolitics, 27-45.

28. Kuus, M. (2009). "Cosmopolitan Militarism? Spaces of NATO Expansion", Environment and Planning A: Economy and Space. 41(3):545-562.

29. Skaric, S., Apasiev, D., \& Patchev, V. (2009). The Name Issue: Greece and Macedonia. Skopje: Matica Makedonska.

30. Treaty of Friendship, Good-neighbourliness, and Cooperation between the Republic of Macedonia and the Republic of Bulgaria. (2017). Retrieved from https://mfa.gov.mk/en/document/1712.

31. Vankovska, B. (2007). The Role of the Ohrid Framework Agreement and the Peace Process in Macedonia. In: Stefano Bianchini et al. (eds.), Regional Cooperation, Peace Enforcement, and the Role of the Treaties in the Balkans, Ravenna: Longo.

32. Vankovska, B. (2017). "Lilliputian Foreign Policy: The Case of the Republic of Macedonia". Security Dialogues, 8(1-2).

33. Vankovska, B. (2020). Geopolitics of the Prespa Agreement: Background and After-Effects. Journal of Balkan and Near Eastern Studies, 22(3), 343-371.

34. Varshney, Ashutosh (2002), 'Ethnic Groups and Civic Life: Hindus and Muslims in India', Yale University Press. 